\title{
The influence of Industry 4.0 on employment in engineering companies: Evidence of managerial view in Czech and Germany
}

\author{
Karel Kuba ${ }^{1}$, Jiri Dedina ${ }^{1}$, and Frantisek Milichovsky ${ }^{2, *}$ \\ ${ }^{1}$ Pan-European University, Faculty of Economics and Entrepreneurship, Tematínska 10, 85105 \\ Bratislava, Slovakia \\ ${ }^{2}$ Brno University of Technology, Faculty of Business and Management, Kolejni 2906/4, 612 00, \\ Brno, Czech Republic
}

\begin{abstract}
Research background: The global business activities raise the necessity of skilled workers, especially in the context of Industry 4.0 and its implementation in company processes. At the same time, the development of technologies in connection with the automation and robotization of production processes. Industry 4.0 provides the company with the opportunity to change from a traditional production approach and separate production units to an automated operation.

Purpose of the article: The primary research aimed to obtain information and data that top managers consider as important. At the same time, there is a focus on the connection between the level of employment in an engineering company and within the implementation of the concept of industry 4.0 .

Methods: In the primary research, structured interviews were used. For the interview, we asked managers from the 88 companies in the Czech and 303 companies in Germany. From that amount, we get responses from $67 \mathrm{Czech}$ companies (82 managers) and 160 German companies (200 managers). Their answers were processed by the Dematel method, which is considered a multi-evaluation tool.

Findings \& Value added: Based on the implementation of the DEMATEL method, the coordinates of individual parameters were determined with their visualization in the map of influences, in which the links between individual variables are visible, which are located in two quadrants. The links between the individual variables are in the form of the above arrows, wherein in the case of bidirectional arrows, it is a mutual influence of variables and oneway arrows then show a one-sided dependence.
\end{abstract}

Keywords: employment; Industry 4.0; Czech Republic; Germany; DEMATEL

\footnotetext{
*Corresponding author: frantisek.milichovsky@vut.cz
} 
JEL Classification: $L 64 ; M 11 ; M 53 ; O 32$

\section{Introduction}

The current dynamics in the business environment raise the need for relevant resources in production. The primary production resources can be considered material, technology, knowhow, as well as experience and knowledge in the form of human capital. Appropriate stimuli can be seen as a result of the opening of domestic markets to the international environment and the gradual globalization of society. In this context, it is important to promote the efficiency and quality of the resources used, not only in the context of the raw materials and technologies used but also in the field of human resources (especially concerning the employment of certain professions).

As a result of the expansion of the global business environment and the resulting relocation of divisions to locations with lower wage levels, it is putting pressure on a sufficient number of skilled workers. At the same time, the development of technologies in connection with the automation and robotization of production processes (application of the Industry 4.0 concept) also hurts this state. Industry 4.0 provides the company with the opportunity to change from a traditional production approach and separate production units to an automated operation. Thanks to this, the interconnection of production systems into one comprehensive virtual environment is achieved, which is referred to as a smart factory.

Industry 4.0 and its primary activities (digitization and automation) require new competencies and knowledge that existing employees must provide to their employer as appropriate adaptations to the changes in the company. Adaptation to new knowledge requirements can be done externally (education system) or in-house options. Adaptation through in-house processes is also referred to as a learning enterprise in connection with Industry 4.0 (Küsters et al., 2017).

In the case of potential employees, companies must define their requirements for new employees. These requirements should then be met by educational institutions that provide relevant knowledge and skills (Benešová and Tupa, 2017). However, the specifics of education in the field of digitization of business processes, not only in the field of production, represent a certain challenge for these educational institutions. A certain problem in education is a certain separation of individual topics with a relatively low level of coherence. However, in the context of vocational education, virtual topics are being developed that lead to the creation of learning enterprises (Wermann et al., 2019).

\subsection{Specification of employment condition according to industry 4.0 concept}

The concept of Industry 4.0 is focused on the use of new production technologies and approaches, as well as the connection of existing technologies to the virtual environment. This connection subsequently creates pressure on the professional development of employees and their further education (Dirgová et al., 2018).

The result of adequate implementation of the whole concept of industry 4.0 through automation and digitization is the reduction of some jobs, which subsequently has certain impacts in the socio-economic and demographic area. Employees affected by such a reduction are very concerned about their further employment in the field. However, due to the requirements for new technologies, at the same time as the mentioned reduction of some jobs, new jobs are also created that meet the requirements from the introduction of new technologies (Tortorella et al., 2020). As possible prevention of the process of job reduction and transfer of a worker to a newly created position, it is necessary for the worker to selfeducate and develop his skills and competencies to achieve new requirements and trends (Dirgová et al., 2018; Budanov et al., 2017; Tourkolias and Mirasgedis, 2011). 
Budanov et al. (2017) list the individual areas that influence employees' opinions on the changes made, regardless of the reasons for these changes. The most significant socioeconomic and demographic impact is that workers fear changes in the working environment ( $44 \%$ of individuals answered in the affirmative), climate change, and natural resources, and $23 \%$ of respondents report some concerns about the middle class in new markets. The fourthplace includes political changes $(21 \%)$, followed by customer behavior $(16 \%)$. Some of these reasons can be directly influenced by the company, while others can only respond to them (see Figure 1).

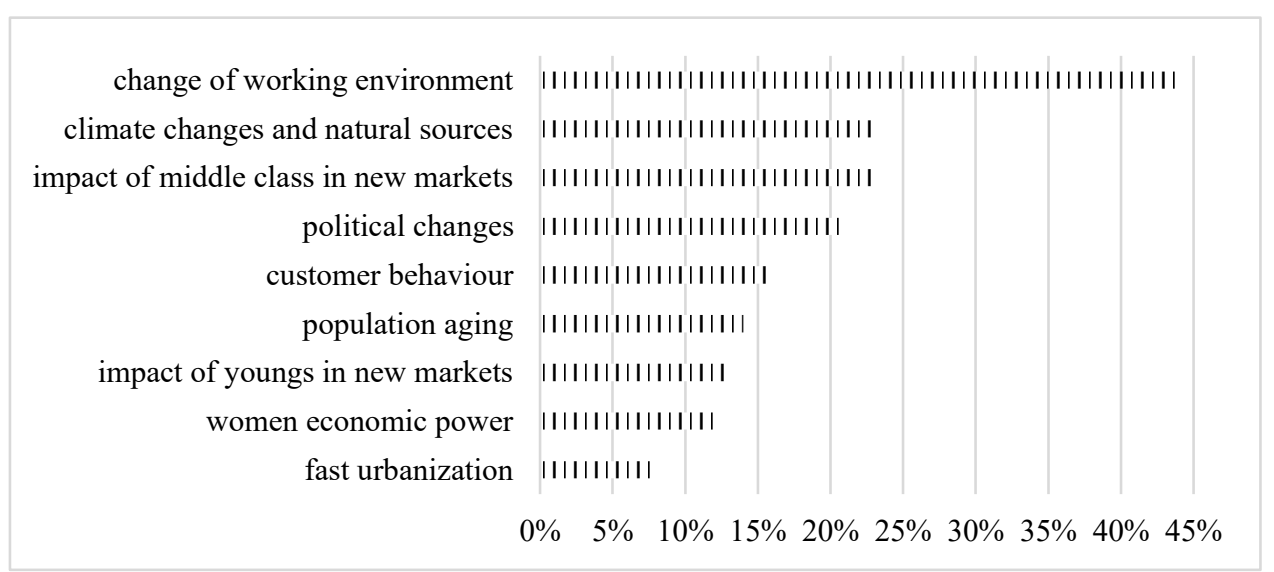

Figure 1. The influence factors in the socio-economic area

Source: Budanov et al. (2017)

\subsection{Requirements specification of new staff in engineering companies}

The comprehensive development of the employee is divided into several different parts, which are focused on an individual direction or company-wide. In the context of companywide education, the use of new educational approaches is encouraged, which can be considered interactive. The main interactive educational approaches include coaching, mentoring, and also e-learning courses. In the case of individual learning, certain stimuli are created, on which the individual subsequently creates other appropriate modules. Great emphasis is placed not only on educational approaches but also on the content and focus of individual approaches. It is therefore important to systematically build knowledge, skills, and abilities with the support of advice, instructions, and other professional instructions and materials. In the case of proper, sustainable, and long-term education, not only the professional competencies of the employee are increased, but also the relevant managers are developed (Pérez-Foguet and Lazzarini, 2019).

Several professions can be included in the group of simple work activities, regardless of the level of education attained. The threat concerns positions that have the character of routine activities. It is, therefore, necessary to focus not only on individuals with low qualifications but also on high school and university graduates. The fundamental key to maintaining existing job positions is their creative focus, social focus, or appropriate level of negotiation. If there is a massive implementation of Industry 4.0 and future generations, all educational institutions, including the existing education system, will have to adapt. The problem, however, is that there is no corresponding consensus on what knowledge and skills graduates should have at different levels of education. Due to the new approaches, it will be expected that these graduates will be able to make systemic decisions and connect individual areas. There is a lack of some knowledge that every graduate should have, regardless of the 
focus of their main field. The most significant shortcomings are considered knowledge of economic and social topics, ability to work with IT, and basic knowledge of production and process management. The connection of these topics into an interdisciplinary form is due to long-term cooperation between companies (regardless of industry) and all types of educational institutions - primary and secondary schools, colleges, universities, and more. Such fundamental changes in the labor market will require radical changes in the educational process, especially in setting the appropriate quality of pedagogical staff who will support students' creative and critical thinking (Kašparová, 2017).

However, to avoid extreme shortfalls in the structure of existing workers, the change in training should be very flexible and aimed at exploiting the potential of workers, regardless of their age. It is necessary not only to address the employment of older people (many older workers still work due to the shift in retirement age) but also to support the employment of graduates and establish cooperation between these generations. It is the experience of older age groups that can very significantly help graduates to enter professional life, and conversely, graduates usually have sufficient knowledge of current tools, approaches, and technologies. Encouraging creativity in training will facilitate the adaptation of the new employee to the appropriate environment. However, the creative ability can "awaken" the creative educator. The need for industrial enterprises for the skills and knowledge of graduates puts pressure on education providers. They consider critical thinking, the ability to solve problems, and the art of decision-making to be key (Serafín et al., 2019; Kašparová, 2017).

The ability to pass on adequate and up-to-date information, which will then be possible to pass on, plays an important role. The graduate should be able to search and work with information, be able to use mathematical skills (analyze problems with logic), etc. In addition to professional prerequisites, appropriate stimuli must be created for the development of personality characteristics that lead to employee independence, competencies), creative practices (innovation), as well as skills and prerequisites for further qualification development. The new possibilities offered by current technologies strongly influence general skills for defining a suitable solution to a problem. Instead of proposing a suitable solution, pressure will be put on the art of evaluating the obtained data and to be able to interpret their results into the in-house education system (Koleňák et al., 2019; Chmura et al., 2019).

\section{Methodology}

The aim of the conducted primary research in the form of interviews was to obtain information and data that top managers consider important in the context of employment levels in the company and connection with the implementation of Industry 4.0 in business processes. Data collection took place through the implementation of structured interviews with top managers in companies that focus on engineering production. These in-depth interviews were conducted between January 2020 and January 2021. In the case of structured interviews with top managers, ninety companies operating in the Czech Republic were interviewed. Of this number, 67 companies with 82 managers (experts) expressed interest in participating in the research. In the case of companies from the Federal Republic of Germany, 303 companies were interviewed. From this number, 160 companies with 200 managers (experts) expressed interest in participating in the research. Priority was given to one of the top managers from each company (executive, human resources manager, production manager, or quality manager) operating in the Czech Republic or the Federal Republic of Germany and to whom I had a connection due to my professional focus.

The structured interviews contained seven questions, to which the elaboration of partial answers was subsequently carried out in connection with the application of the DEMATEL 
method. Furthermore, a summary evaluation of the obtained data and information of interviews in the form of a verbal description was performed.

\section{Results and Discussion}

The DEMATEL method helps to examine the dependence between selected variables. All calculations in the DEMATEL method were proved in MS Excel. In this case, it is a statement of TOP managers on four specified issues and their links. Individual managers were understood as responsible experts for the needs of fulfilling the requirements of the DEMATEL methods (Leksono et al., 2019). Relevant questions were asked to all representatives of TOP management in selected companies, to which they answered in the form of a scale. It is about:

- Do you have a concrete idea of how the 4th Industrial Revolution will affect you? (hereinafter is used coding Idea)

- Do you expect an early return on investment in automation and robotics? (the coding Return is also used)

- Would you invest in robotics at your workplace even in the case of special extra taxation on robotic work? (hereinafter referred to as Investment coding)

- What is your experience with implementing Industry 4.0 and other areas of system integration? (hereafter using Experience coding)

However, for the needs of the DEMATEL method, individual managers were asked to express perceived links between other questions with a focus on influencing other parameters (Zhang et al., 2020). In the context of the method, it is then a matter of defining the input criteria. These managers received appropriate instructions on the expression of perceived relationships and the definition of the direct influence of the criteria on criterion $\mathrm{j}$. Based on their answers, partial matrices Xk was created for each manager. To be able to proceed, it is essential to create an average matrix A, which is processed based on averaging the matrices of individual managers. The resulting average matrix A is then shown in Table 1.

Table 1. Average matrix A for defined criteria

\begin{tabular}{|c|c|c|c|c|c|c|}
\hline & & Idea & Return & Investment & Experience & Total \\
\hline \multirow{4}{*}{$\begin{array}{c}\text { Czech } \\
\text { republic }\end{array}$} & Idea & 0 & 2,407 & 2,293 & 2,305 & $\mathbf{7 , 0 0 5}$ \\
\cline { 2 - 7 } & Return & 2,537 & 0 & 2,183 & 2,341 & $\mathbf{7 , 0 6 1}$ \\
\cline { 2 - 7 } & Investment & 2,317 & 2,390 & 0 & 1,768 & $\mathbf{6 , 4 7 6}$ \\
\cline { 2 - 7 } & Experience & 2,390 & 2,366 & 1,963 & 0 & $\mathbf{6 , 7 2 0}$ \\
\cline { 2 - 7 } & Total & $\mathbf{7 , 2 4 4}$ & $\mathbf{7 , 1 6 4}$ & $\mathbf{6 , 4 3 9}$ & $\mathbf{6 , 4 1 5}$ & \\
\hline \multirow{4}{*}{ Germany } & Idea & 0 & 2,490 & 2,545 & 2,437 & $\mathbf{7 , 4 7 2}$ \\
\cline { 2 - 7 } & Return & 2,590 & 0 & 2,680 & 2,628 & $\mathbf{7 , 8 9 8}$ \\
\cline { 2 - 7 } & Investment & 2,430 & 2,705 & 0 & 2,317 & $\mathbf{7 , 4 5 2}$ \\
\cline { 2 - 7 } & Experience & 2,305 & 2,570 & 2,200 & 0 & $\mathbf{7 , 0 7 5}$ \\
\cline { 2 - 7 } & Total & $\mathbf{7 , 3 2 5}$ & $\mathbf{7 , 7 6 5}$ & $\mathbf{7 , 4 2 5}$ & $\mathbf{7 , 3 8 2}$ & \\
\hline
\end{tabular}

Source: own work

For further evaluation, it is necessary to convert the average matrix A into a normalized form - i.e. into matrix D. For this normalization it is necessary to indicate the maximum value 
of row and column sums from the average matrix A. The highest value for row sum is 7,061 for the Czech Republic and 7,898 for Germany, and 7,244 for the Czech Republic, and 7,765 for Germany for the column sum. These values are then expressed in inverse value $(1 / \max )$ and the lower one is then selected from these inverse values, thus achieving the value $\lambda$. The resulting value of $\lambda$ is then equal to 0.138047 (Czech Republic) and 0.126612 (Germany). This value of $\lambda$ is then used to determine the normalized matrix D. The resulting normalized matrix $\mathrm{D}$ and the individual values are given in Table 2.

Table 2. Normalized matrix D for defined criteria

\begin{tabular}{|c|c|c|c|c|c|}
\hline & & Idea & Return & Investment & Experience \\
\hline \multirow{4}{*}{$\begin{array}{c}\text { Czech } \\
\text { republic }\end{array}$} & Idea & 0 & 0,332 & 0,316 & 0,318 \\
\cline { 2 - 6 } & Return & 0,350 & 0 & 0,301 & 0,323 \\
\cline { 2 - 6 } & Investment & 0,320 & 0,330 & 0 & 0,244 \\
\cline { 2 - 6 } & Experience & 0,330 & 0,327 & 0,271 & 0 \\
\hline \multirow{4}{*}{ Germany } & Idea & 0 & 0,315 & 0,322 & 0,309 \\
\cline { 2 - 6 } & Return & 0,328 & 0 & 0,339 & 0,333 \\
\cline { 2 - 6 } & Investment & 0,308 & 0,342 & 0 & 0,293 \\
\cline { 2 - 6 } & Experience & 0,292 & 0,325 & 0,279 & 0 \\
\hline
\end{tabular}

Source: own work

The values tij are then determined for the determination of direct and indirect effects, and a matrix of total effects $\mathrm{T}$ is created. This matrix is given including the required values ri and $\mathrm{cj}$, which are then used to determine the $\mathrm{X}$ and $\mathrm{Y}$ coordinates (see Table 3). To determine the positive effects between the elements, gained values (that exceed the threshold value $\alpha$ ) are highlighted. This threshold value of $\alpha$ is equal to 4.061 for the Czech Republic and 4.450 for Germany.

Table 3. Matrix $\mathrm{T}$ of final influences for defined criteria

\begin{tabular}{|c|c|c|c|c|c|c|}
\hline & & Idea & Return & Investment & Experience & $\mathbf{r}_{\mathbf{i}}$ \\
\hline \multirow{4}{*}{$\begin{array}{c}\text { Czech } \\
\text { republic }\end{array}$} & Idea & 4,149 & 4,360 & 4,037 & 4,033 & $\mathbf{1 6 , 5 7 8}$ \\
\cline { 2 - 7 } & Return & 4,436 & 4,138 & 4,053 & 4,062 & $\mathbf{1 6 , 6 8 9}$ \\
\cline { 2 - 7 } & Investment & 4,154 & 4,124 & 3,580 & 3,773 & $\mathbf{1 5 , 6 3 0}$ \\
\cline { 2 - 7 } & Experience & 4,274 & 4,235 & 3,897 & 3,680 & $\mathbf{1 6 , 0 8 5}$ \\
\cline { 2 - 7 } & $\mathbf{c}_{\mathbf{j}}$ & $\mathbf{1 7 , 0 1 2}$ & $\mathbf{1 6 , 8 5 7}$ & $\mathbf{1 5 , 5 6 7}$ & $\mathbf{1 5 , 5 4 7}$ & \\
\hline \multirow{4}{*}{ Germany } & Idea & 4,204 & 4,632 & 4,492 & 4,465 & $\mathbf{1 7 , 7 9 4}$ \\
\cline { 2 - 7 } & Return & 4,630 & 4,579 & 4,683 & 4,459 & $\mathbf{1 8 , 5 5 1}$ \\
\cline { 2 - 7 } & Investment & 4,437 & 4,644 & 4,246 & 4,453 & $\mathbf{1 7 , 7 8 0}$ \\
\cline { 2 - 7 } & Experience & 4,261 & 4,461 & 4,296 & 4,059 & $\mathbf{1 7 , 0 7 8}$ \\
\cline { 2 - 7 } & $\mathbf{c}_{\mathbf{j}}$ & $\mathbf{1 7 , 5 3 2}$ & $\mathbf{1 8 , 3 1 7}$ & $\mathbf{1 7 , 7 1 7}$ & $\mathbf{1 7 , 6 3 6}$ & \\
\hline
\end{tabular}

Source: own work 
The most influencing parameter for the Czech Republic is with the value $r_{i}$ Return $\left(r_{i}=\right.$ $16,689)$. From the point of view of the highest value of $c_{j}$, the important parameter is the Idea $\left(c_{j}=17,012\right)$. In the case of the most important parameters for Germany, the value of $r_{i}$ is the Return $\left(r_{i}=18,551\right)$. From the point of view of the highest value of $c_{j}$, the return parameter $\left(c_{j}=18,317\right)$ is an important parameter. The resulting influence map requires the determination of the respective $\mathrm{X}$ and $\mathrm{Y}$ coordinates for each parameter The individual values for the coordinates are then determined (see Table 4).

Table 4. Final coordinates for defined criteria

\begin{tabular}{|c|c|c|c|c|}
\hline \multirow{2}{*}{} & \multicolumn{2}{|c|}{ Czech republic } & \multicolumn{2}{c|}{ Germany } \\
\cline { 2 - 5 } & $\mathbf{r}_{\mathbf{j}}+\mathbf{c}_{\mathbf{i}}$ & $\mathbf{r}_{\mathbf{j}}-\mathbf{c}_{\mathbf{i}}$ & $\mathbf{r}_{\mathbf{j}}+\mathbf{c}_{\mathbf{i}}$ & $\mathbf{r}_{\mathbf{j}}-\mathbf{c}_{\mathbf{i}}$ \\
\hline Idea & 33,59050 & $-0,43370$ & 35,32581 & 0,26157 \\
\hline Return & 33,54620 & $-0,16756$ & 36,86804 & 0,23390 \\
\hline Investment & 31,19712 & 0,06329 & 35,49780 & 0,06314 \\
\hline Experience & 31,63227 & 0,53796 & 34,71411 & $-0,55861$ \\
\hline Coordinates & $\mathbf{X}$ & $\mathbf{Y}$ & $\mathbf{X}$ & $\mathbf{Y}$ \\
\hline
\end{tabular}

Source: own work

These coordinates are then used to display individual elements in the Cartesian coordinate system. The graphical representation of the analyzed variables in terms of their perception by business experts is then shown in Figure 2, both for Czech companies and German companies.

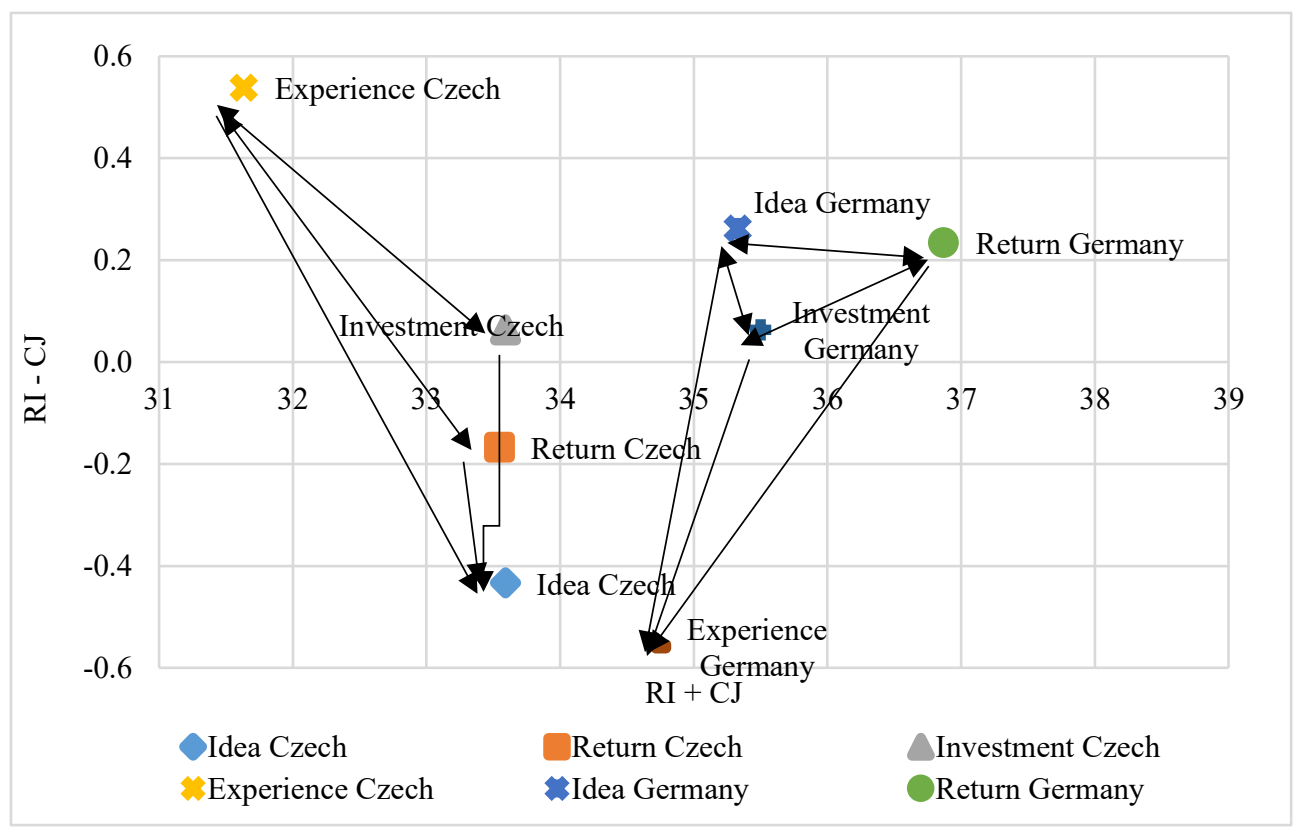

Figure 2. The influence map of chosen criteria for the Czech Republic and Germany

Source: own work 
The map of influences shows visible connections between individual variables in each country, which are placed in two quadrants; namely the investment of the Czech Republic and the experience of the Czech Republic, the idea of Germany, the return of Germany, and the investment of Germany in the first quadrant, and return of the Czech Republic, the idea of the Czech Republic and the experience of Germany in the fourth quadrant. The connections between the individual variables are in the form of the above arrows, wherein in the case of bidirectional arrows, it is a mutual influence of variables and one-way arrows then show a one-sided dependence.

\section{Conclusion}

Business owners see the Industry 4.0 concept as a great opportunity, despite their low awareness of the concept. Thanks to the spread of this concept, the fact that individual workers will have to increase their qualifications, especially in manual occupations, is already accepted among managers in companies. The consequence of this situation will be a reduction in the number of employees by unsuitable adepts and the possibility of replacing them with machines (Malý, 2017; Telukdarie et al., 2018). Thanks to the application of individual elements of Industry 4.0 to the business environment, it is possible to anticipate the improvement of interconnected business areas. As a result of this implementation, Zezulka et al. (2016) creation of new business models, digital mediation of offered products and services, and digitization and integration of all technical elements with their economy. The process of introducing new technologies and changes in the qualification requirements of employees can be seen as a big problem in companies. Within business and marketing activities, there will be changes in work, when pre-set business offers will be gradually dismantled and employees will have to work strongly creatively with a focus on their personal development (Malý, 2017; Kohnová et al., 2019; Dědina \& Dědina, 2008).

The importance of all the aspects that Industry 4.0 brings to society can be considered so fundamental that changes are expected in all areas of human life. As a result of the implementation of all aspects, a comprehensive and automated system will be created, which will be entered in a minimum of cases (all will be done by autonomous systems) and usually only to control or correct settings (this will require very sophisticated knowledge and skills). As the requirements for professional knowledge increase, there will be a certain gradation, when highly qualified individuals will be extraordinarily heavily sought after in the labor market. Conversely, individuals with low or no qualifications who perform simple and repetitive activities in the current production environment will be a highly vulnerable group. For these reasons, there will be pressure on all educational institutions (schools, educational and counseling centers, etc.) to adapt educational programs as much as possible to these pressures and requirements. However, these changes may not be sufficient, because the advent of automated systems and technologies will reduce the need for human labor in the long run, regardless of the location of the state and its current economic maturity (Červený, 2016).

\section{References}

1. Benešová, A., \& Tupa, J. (2017). Requirements for education and qualification of people in Industry 4.0. Procedia Manufacturing, 11, 2195-2202.

2. Budanov, V., Aseeva, I., \& Zvonova, E. (2017). Industry 4.0: Socio-economic junctures. Economic Annals-XXI, 168(11-12), 33-37. 
3. Červený, K. (2016). Průmyslová revoluce 4.0, 5.0, 6.0 nebo 7.0? Technický týdeník. https://www.technickytydenik.cz/rubriky/ekonomika-byznys/prumyslova-revoluce-40-5-0-6-0-nebo-7-0_35493.html

4. Chmura, M., Malach, J., \& Vicherková, D. (2019). The significance of digital competences of university teachers: The views of the teachers and students themselves. International Conference e-Society, 135-142.

5. Dědina, J., \& Dědina, J. (2008). Analysis and comparison of managerial styles of czech and foreign managers. Ekonomia a podnikanie, 2(2), 13-27.

6. Dirgová, E., Janičková, J., \& Klencová, J. (2018). New trends in the labor market in the context of shared economy. TEM Journal, 7(4), 791-797.

7. Kašparová, J. (2017). Průmysl 4.0, Vzděláváni 4.0, Práce 4.0 a Společnost 4.0. Praha: Českomoravská konfederace odborových svazů.

8. Kohnová, L., Papula, J., \& Salajová, N. (2019). Internal factors supporting business and technological transformation in the context of Industry 4.0. Business: Theory and Practice, 20, 137-145.

9. Koleňák, J., Ullrich, D., Ambrozová, E., \& Pokorný, V. (2019). Critical thinking and leadership in industry 4.0 environment. Vision 2025: Education excellence and management of innovations through sustainable economic competitive advantage, 18261836.

10. Küsters, D., Praß, N., \& Gloy, Y.-S. (2017). Textile learning Factory 4.0 - preparing Germany's textile industry for the digital future. Procedia Manufacturing, 9, 214-221.

11. Leksono, E. B., Suparno, S., \& Vanany, I. (2019). Integration of a Balanced Scorecard, DEMATEL, and ANP for measuring the performance of a sustainable healthcare supply chain. Sustainability, 11, 1-18.

12. Malý, M. (2017). Průmysl 4.0 - více než jen průmysl! https://www.lupa.cz/clanky/senzory-martina-maleho-prumysl-4-0-vice-nez-jenprumysl/

13. Pérez-Foguet, A., \& Lazzarini, B. (2019). Continuing professional education in engineering faculties: Transversal integration of sustainable human development in basic engineering sciences courses. Journal of Cleaner Production, 218, 772-781.

14. Serafín, Č., Depešová, J., \& Bánesz, G. (2019). Understanding digital competences of teachers in Czech Republic. European Journal of Science and Theology, 15(1), 125-132.

15. Telukdarie, A., Buhulaiga, E., Bag, S., Gupta, S., \& Luo, Z. (2018). Industry 4.0 implementation for multinationals. Process Safety and Environmental Protection, 118, 316-329.

16. Tortorella, G. L., Cawley Vergara, A. M., Garza-Reyes, J. A., \& Sawhney, R. (2020). Organizational learning paths based upon industry 4.0 adoption: An empirical study with Brazilian manufacturers. International Journal of Production Economics, 219, 284-294.

17. Tourkolias, C., \& Mirasgedis, S. (2011). Quantification and monetization of employment benefits associated with renewable energy technologies in Greece. Renewable and Sustainable Energy Reviews, 15(6), 2876-2886.

18. Wermann, J., Colombo, A. W., Pechmann, A., \& Zarte, M. (2019). Using an interdisciplinary demonstration platform for teaching Industry 4.0. Procedia Manufacturing, 31, 302-308.

19. Zezulka, F., Marcon, P., Vesely, I., \& Sajdi, O. (2016). Industry 4.0 - An introduction in the phenomena. IFAC-Papers Online, 49-25, 8-12. 
20. Zhang, X., Ming, X., \& Yin, D. (2020). Application of industrial big data for smart manufacturing in product service system based on system engineering using fuzzy DEMATEL. Journal of Cleaner Production, 265, 1-25. 